\title{
Integrated Waste Management in PT. PJB UP Muara Tawar
}

\author{
Miradha Herdini Widiatmi ${ }^{1}$, Syaiful Amin ${ }^{1}$, Awang Asmoro ${ }^{1}$, \\ Catur Budi Prasetyo ${ }^{1}$, Kevin Sanjoyo Gunawan ${ }^{2}$, Totok R. Biyanto ${ }^{2 *}$ \\ ${ }^{I}$ PT. PJB UP Muara Tawar, Muara Tawar, Indonesia \\ ${ }^{2}$ Engineering Physics Department, Institut Teknologi Sepuluh Nopember (ITS), Surabaya, Indonesia.
}

\begin{abstract}
Now a day environmental issues, especially the domestical solid waste/garbage problems in Bekasi Distric are still an unresolved problem. The waste increase over the time due to increase in population and human activities. The waste problem are also an important issue for PT. PJB UP Muara Tawar power plant. The waste will contaminate the rain and river water then flow to the sea. As we know, the power plant condenser utilize sea water as cooling fulid. The sea water will flow through pump and filter. The waste contamined in water sea has posibility to clog the intake of filter. From management of PT. PJB UP Muara Tawar point of view, the sea water polution due to solid waste can affect the operation and maintenance of power plant, as well as the impact to the public healthy. Hence, this program is very important to the company and society and it is in line with Sustainable Development Goals (SDGs) i.e. "clean water and proper sanitation". This program was initiated by PT. PJB UP Muara Tawar and it is perfomed by society with the main objective i.e. increasing the income of society, improve clean environmental and society healthy. The program is performed by collecting garbage at waste processing facilities then sorted according to its type (paper or plastic). Plastic waste will be washed in the tub to remove dirt and put into the washing machine for further cleaning process. The waste put into the press machine to solidify and then the garbage sold to garbage collectors. This program have been succesfull implemented. From this program the society have been educated and achieve an extra income about IDR 5.9 million per month or in another word, this program can reduce waste about 2.5 tons per month.
\end{abstract}

Keywords: paper, plastic, recycle, waste

\section{Introduction}

Now a day environmental issues, especially the domestical solid waste/garbage problems in Bekasi Distric are still an unresolved problem. The waste increase over the time due to increase in population and human activities [1]. The waste reqiure processing fasilities or plant and transportation to deliver it [2]. However, the availability of transportation vehicle can not meet with waste volume rate, hence the waste accumulation are the increase and stack at some area generate polution especially bad smell. In order to evercome this matter, some people burn the waste and increase air polution [3]. This chase have been happened in Segarajaya Village area, especially at Kampung Mandalajaya, Kampung Paljaya, and Kampung Kaliadem.

The waste problem are also an important issue for PT. PJB UP Muara Tawar power plant. The waste will contaminate the rain and river water then flow to the sea. As we know, the power plant condenser utilize sea water as cooling fulid. The sea water will flow through pump and filter. The waste contamined in water sea has posibility to clog the intake of filter.

From management of PT. PJB UP Muara Tawar point of view, the sea water polution due to solid waste can affect the operation and maintenance of power plant, as well as the impact to the public healthy. Hence, this program is very important to the company and society and it is in line with Sustainable Development Goals (SDGs) i.e. "clean water and proper sanitation" [4].

This program was initiated by PT. PJB UP Muara Tawar and it is perfomed by society with the main objective i.e. increasing the income of society, improve clean environmental and society healthy [5]. There are two group that will be involved in this program i.e. fishermen and women groups. The women group is full time worker while the fishermen group is part time worker that will parcipitate after fishing as their regular work. Both groups will recover the plastic and paper materials from garbage, deliver and sell it to waste collector that will processed it further .

In order to increase effectiveness of this program, district government participation is required to educate the society regarding technique to select useful garbage, healthy, green practice and mangrove ecotourism program in Paljaya. The program is performed from 2014 until 2018. 


\section{Theory}

The definition of waste management of $3 R$ is the effort to reduce waste disposal through reuse, reducing, and recycle the waste. Reuse is the direct reuse of waste for the same or other functions. Reduce is reducing goods consumption such as paperless, etc. Recycle is reprocessing and reuse the waste for other purposes [6].

Sources of waste can vary from households, markets, stalls, offices, public buildings, industries, and roads. Based on their chemical composition, the waste is divided into organic waste and inorganic waste. Research on solid waste in Indonesia shows that $80 \%$ waste is organic waste, and it is estimated that $78 \%$ of the waste can be reused [7].

Waste management or Waste disposal is all the activities and actions required to manage waste from its inception to its final disposal [8]. This includes amongst other things, collection, transport, treatment and disposal of waste together with monitoring and regulation. It also encompasses the legal and regulatory framework that relates to waste management encompassing guidance on recycling etc.

\section{Method}

The integrated waste processing program requires several resources, including human resources, as garbage collector, trainer and administrator. Another source is the facilities for garbage collection, sorting, washing and pressing, such as carts, trash cans, scales, etc. And the last resource is the waste itself, especially plastic waste and paper.

The program is performed by the following stages:

1. Collecting garbage at waste processing facilities

2. The collected garbage is sorted according to its type. Processed waste is plastic and paper waste. Unprocessed waste will be collected and sent to the landfills by district government.

3. Plastic waste will be washed in the tub to remove dirt and put into the washing machine for further cleaning process.

4. Put the waste into the press machine to solidify the garbage.

5. Weighting and sold the garbage to garbage collectors.

\section{Discussion}

In implementation of the program, the problem rise from lack of information or ignorance of society that the waste can be converted to money and culture resistant. These problem can be eliminated by educate the society through traditional local leader that have influence to the society. Continous improvement in this program shows the changing of society culture.

By this program society are becoming aware of economic value from waste. With this awareness, they have been motivated to collect and processed the garbage. Moreover the extra income prove this program is easy and very useful for their life and society. This behavior happen in several years and it is become the habit and culture of society.

In order to plan, do, control, action (PDCA) of this program, the company also appoint the third party to do this purpose. The third party will assist the society in term of technical or non technical matters. The evaluation is conduncted monthly by third party as monthly report to the company.

As mentioned before, the success of this program depends on all involved parties i.e. the company, third party, local government, society and garbage collector. The progress of the program is monitored and regularly evaluated by the company and third party. Evaluation of the program is performed twice a year in June and December. Some performance indicators are the achievability of the program, society response, the suitability of program indicators, implementation schedule, and effectiveness of budget. The program indicator consists of the number of participants in this program, the amount of waste collected, the gross of useful waste, the net of waste that can be processed and income.

The society collect the waste once a week. From this program the society can achieve an extra income about IDR 5.9 million per month or in another word, this program can reduce waste about 2.5 tons per month. Now a days, the society have been performed this program by theirself and the next program that they propose the processing of organic waste for compost and inorganic waste processing to produce recycle goods.

\section{Conclusion}

This program have been succesfull implemented. From this program the society have been educated and achieve an extra income about IDR 5.9 million per month or in another word, this program can reduce waste about 2.5 tons per month. 


\section{Acknowledgement}

The authors gratefully thank to PT. PJB UP Muara Tawar - Indonesia for providing the facilities in conducting this research.

\section{References}

[1]. N. Kim and P. Q. Long, "Solid waste management associated with the development of 3R initiatives: case study in major urban areas of Vietnam," Journal of Material Cycles and Waste Management, vol. 13, pp. 25-33, 2011

[2]. C. F. S. Bargigli and S. Ulgiati, "Life cycle assessment (LCA) of waste managementstrategies: Landfilling, sorting plant and incineration.," Energy, vol. 34, no. 12, pp. 2116-2123, 2009.

[3]. Ling and I. Hoe, "Estimation of municipal solid waste landfill settlement," Journal of Geotechnical and Geoenvironmental, vol. 124, no. 1 , pp. 21-28, 1998 .

[4]. McDougall and R. Forbes, Integrated Solid Waste Management: A Life Cycle Inventory., John Wiley \& Sons, 2008

[5]. Aye, Lu and E. R. Widjaya, "Environmental and economic analyses of waste disposal options for traditional markets in Indonesia," Waste Management, vol. 26, no. 10, pp. 1180-1191, 2006

[6]. Gadde, Syam, M. Rabinovich and J. Chase, "Reduce, reuse, recycle: An approach to building largeinternet caches," Operating Systems, 1997.

[7]. S. M. Schaub and J. J. Leonard, "Composting: An alternative waste management option for food processing industries," Trends in food science \& technology, vol. 7, no. 8, pp. 263-268, 1996.

[8]. "United Nations Statistics Division - Environment Statistics," [Online]. Available: unstats.un.org. [Accessed 215 2017]. 